\title{
CONTRIBUTION OF LIGNITE IN THE GREEK ECONOMY
}

\author{
Karageorgiou D. E. ${ }^{1}$, Metaxas A. ${ }^{1}$, Dimitriou D. ${ }^{1}$, Arapogiannis E. ${ }^{1}$ \\ and Varvarousis G. ${ }^{1}$ \\ ${ }^{1}$ Institute of Geology and Mineral Exploration, Olympic Village, Entrance C 13677 Acharnae Greece \\ dek@igme.gr
}

\begin{abstract}
The objective of the present work is the assessment of the lignite contribution to the energy balance of Greece, according to the creation processes and the chronological classification.

The lignite deposits known so far in Greece have been discovered and researched from the scientists of IGME in the course of evolution since 1948 (Greek Geological Survey), 1950 (Institute of Geology and Surface Research), 1973 (National Institute of Geological and Mineral Exploration) and finally in its current form in 1976 (Institute of Geology and Mineral Exploration) and are divided into (a) "productive", (b) future "productive" and (c) no financial interest in power generation. A project, co-financed by the Greek Government and the European Union, is currently implemented, aiming at the recovery of the latter in non-electrical purposes with very good results in the first stage of research.

According to the works carried out so far it has been observed that lignite formation started in Greece during Eocene and continued to date.

From 1950 until today there is an upward trend in lignite reserves. Lignite generates electricity at a rate $63 \%$ today with higher rates $79.3 \%$, during 1994.

In Greece $41 \%$ of lignite deposits were created during Miocene. However, only $13 \%$ of these deposits that contribute to electricity generation derive from economically exploitable reserves.

In Greece, due mainly to use of lignite for electricity production, the cost of Kw/h for both domestic use and for industrial is below the European Union average.
\end{abstract}

Key words: lignite, energy balance, chronological classification and electricity.

\section{Introduction}

The objective of the present work is the assessment of the lignite contribution to the energy balance of Greece, according to the creation processes and the chronological classification.

Furthermore, it was observed that lignite creation in Greece started during Eocene and that $41 \%$ of the lignite deposits were formed during Miocene. However, only $13 \%$ of the deposits contributing to electricity generation derive from economically exploitable reserves.

\section{Chronological Classification}

The lignite deposits known so far in Greece have been discovered and researched from the scientists of IGME in the course of evolution since 1948 (Greek Geological Survey), 1950 (Institute of 


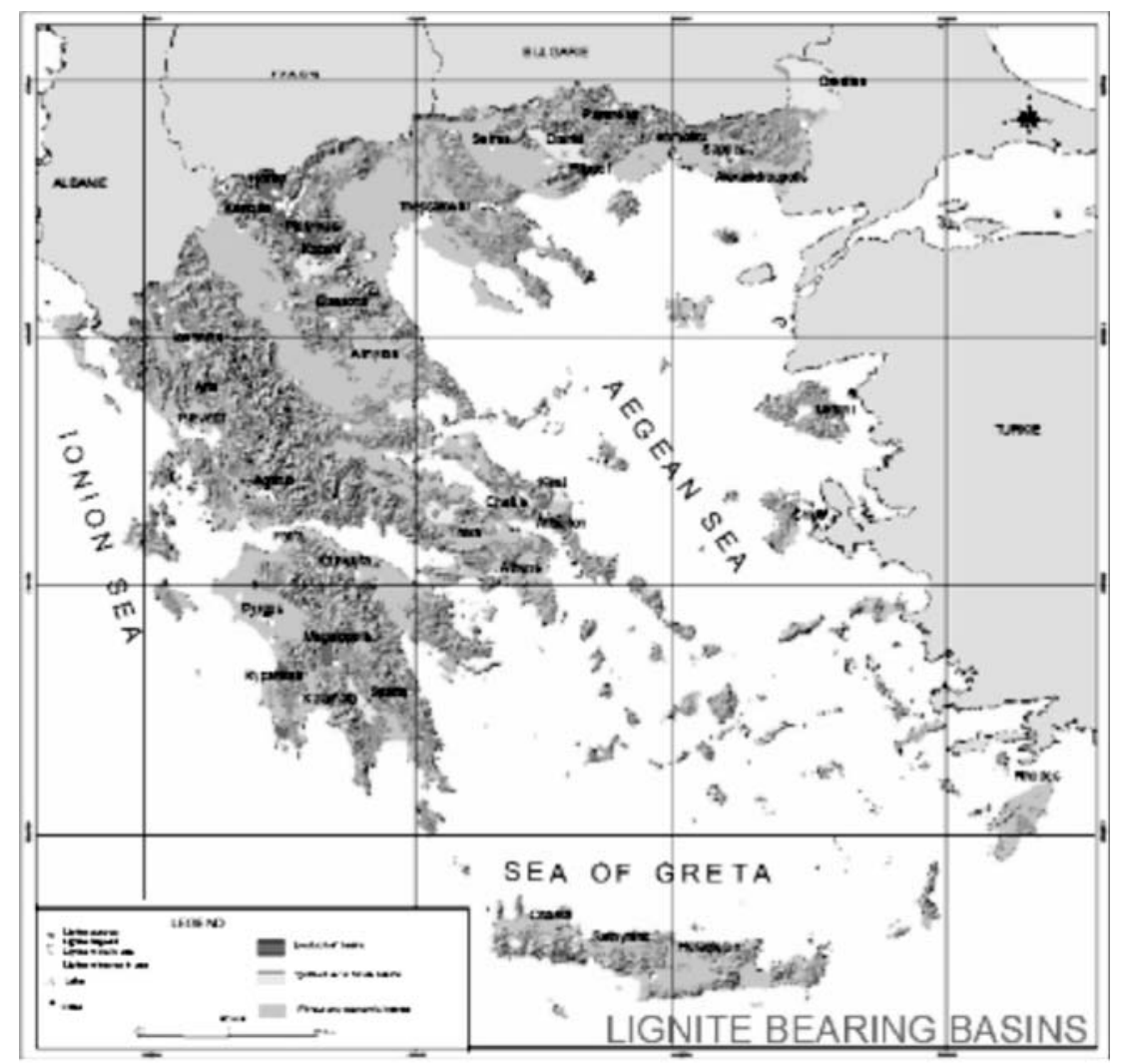

Fig. 1: Map of Greek lignite bearing basins classification.

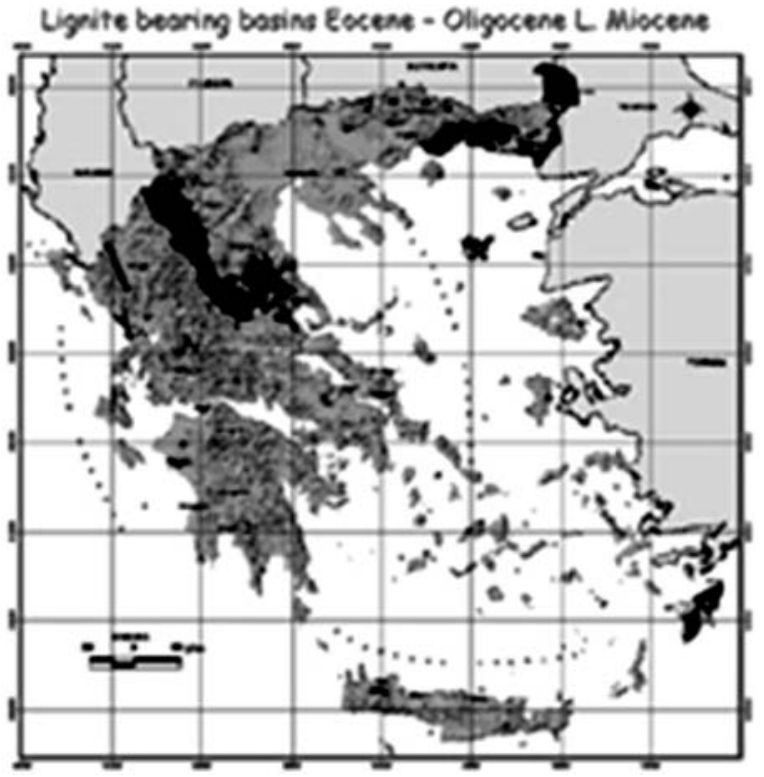

Fig. 2: Map of Eocene - L. Miocene Greek lignite bearing basins. 


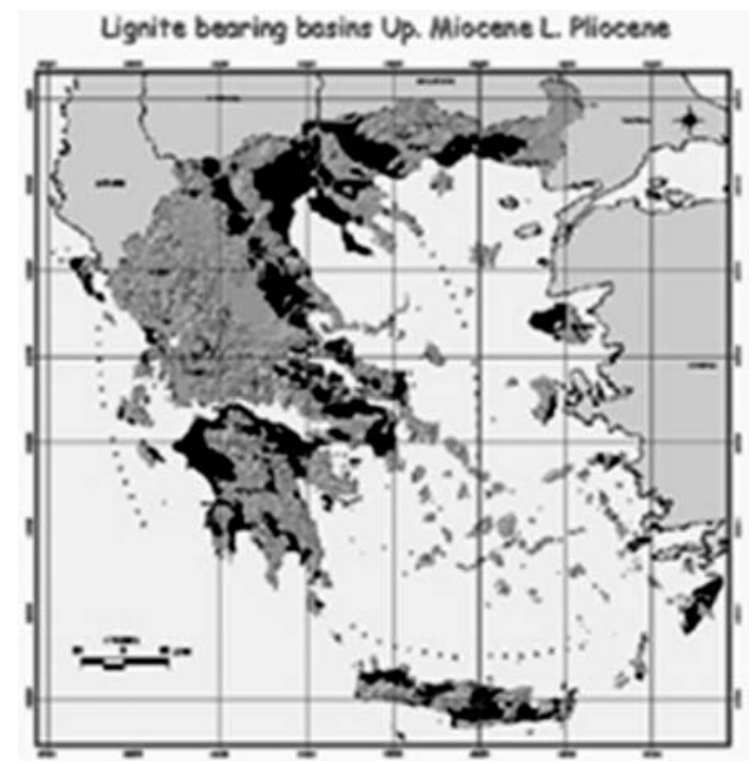

Fig. 3: Map of Up. Miocene - L. Pliocene Greek lignite bearing basins.
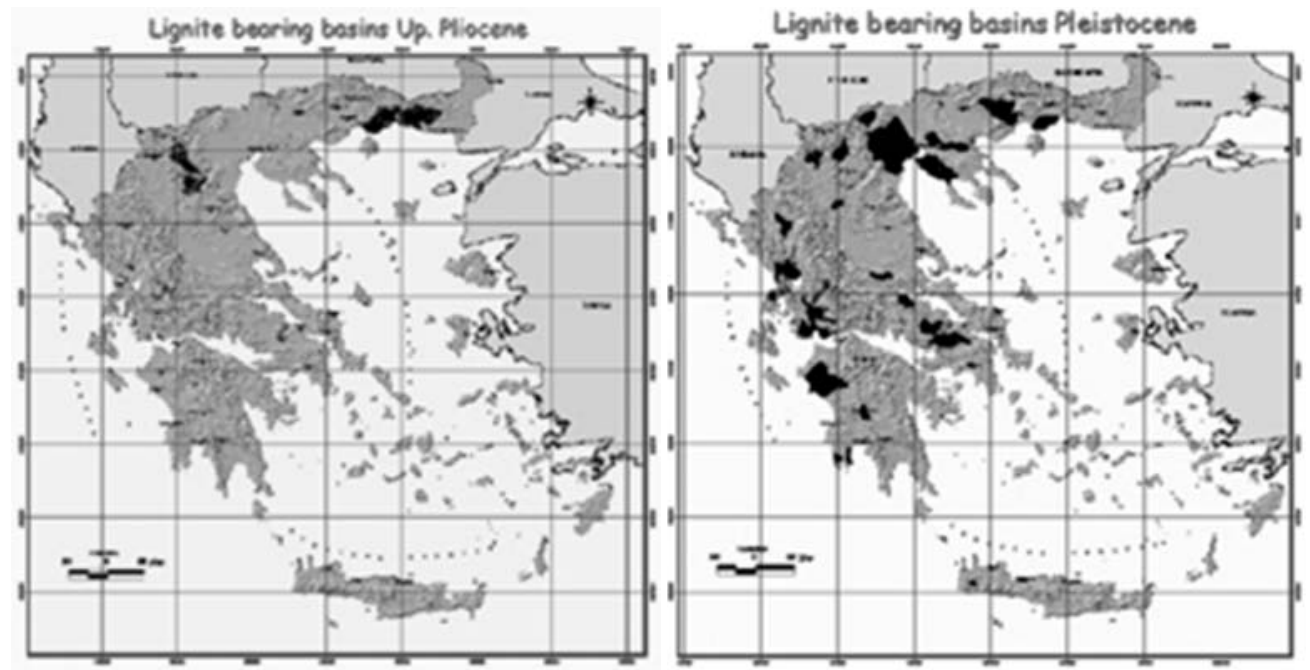

Fig. 4: Map of Up. Pliocene Greek lignite bearing basins. Fig.5: Map of Pleistocene Greek lignite bearing basins.

Geology and Surface Research), 1973 (National Institute of Geological and Mineral Exploration) and finally in its current form in 1976 (Institute of Geology and Mineral Exploration) and are divided into (a) "productive", (b) future "productive" and (c) no financial interest in power generation. A project, co-financed by the Greek Government and the European Union, is currently implemented, aiming at the recovery of the latter in non-electrical purposes with very good results in the first stage of research (Fanara and Chatzigiannis, 1999).

According to the studies implemented so far, the chronological classification of the Hellenic territory is illustrated in figs 1,2,3,4 and 5. In Greece, lignite formation started during Eocene and continued to date (Metaxas et al., 2007). 


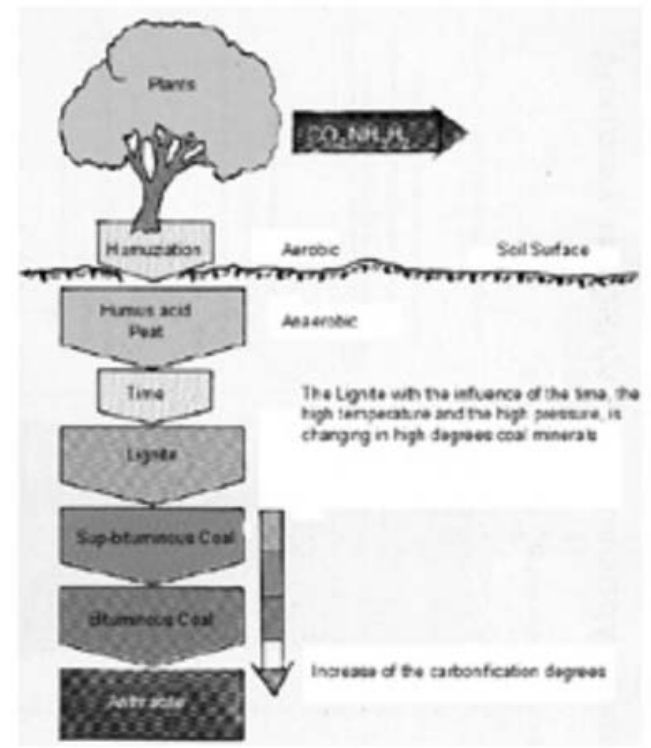

Fig. 6: General view of lignite formation.

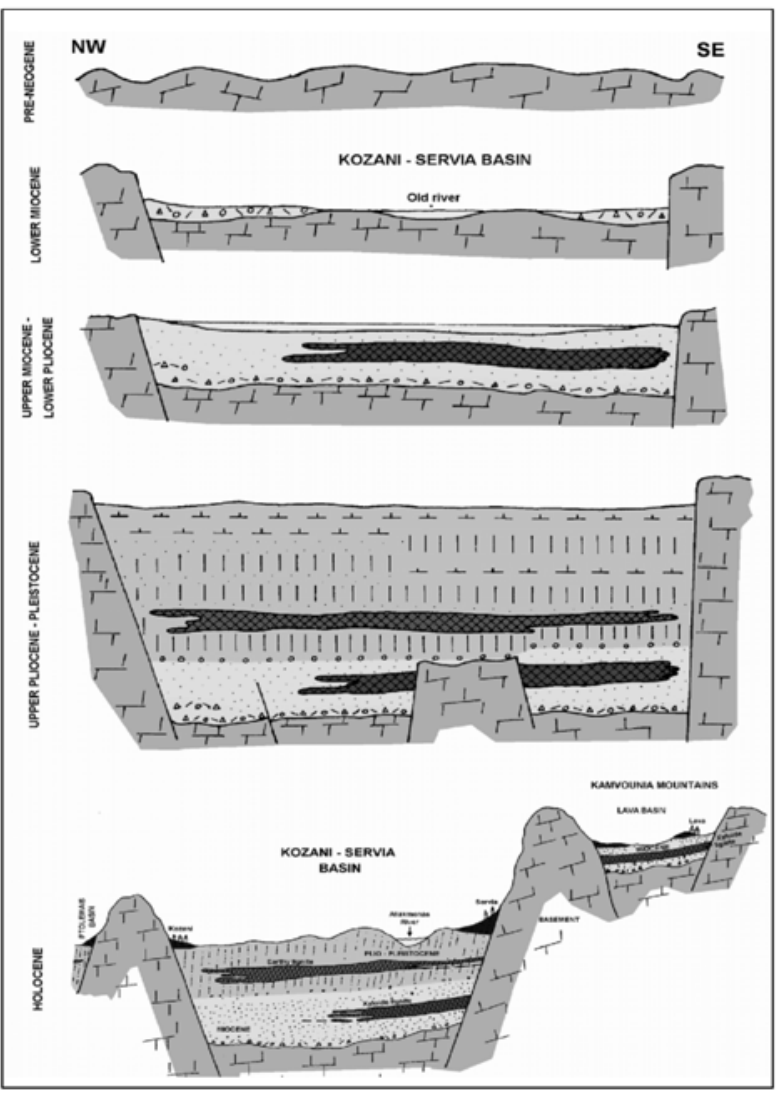

Fig. 7: Different phases of the Kozani Servia lignite bearing basin. 

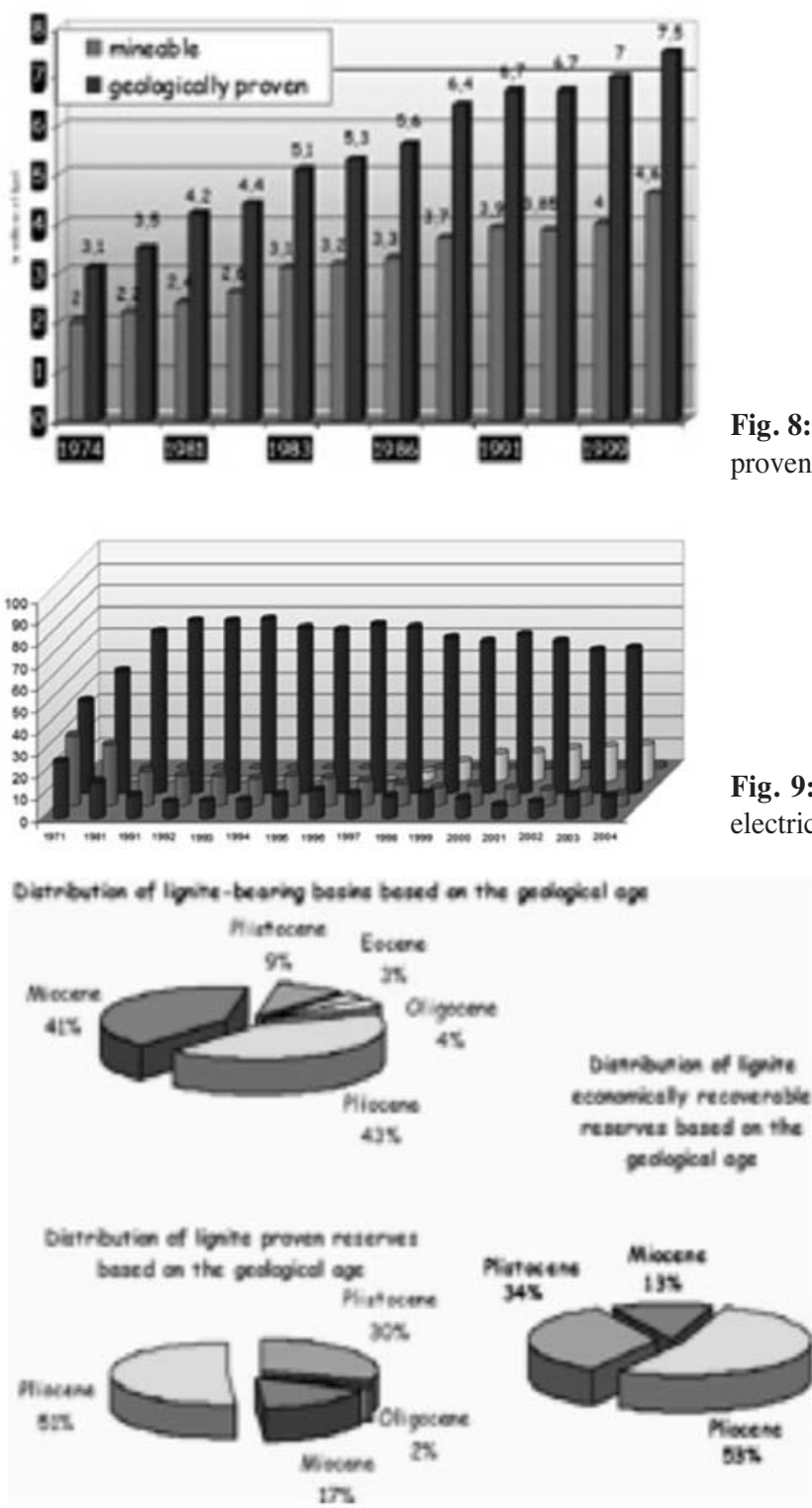

Fig. 8: Greek lignite mine able and geological proven reserves.

Fig. 9: The contribution of the lignite in the electricity in Greece.

A schematic representation of the general creation way of lignite is given in figure 6, while in figure 7 is schematically given the creation of the lignite-bearing basin Kozani - Servia.

\section{Participation of Lignite in the Energy Balance}

From 1950 to date, there was an upward trend in the participation of the lignite reserves (Fig. 8) As indicated in figure 9 , lignite contributes to electricity generation at a percentage of $63 \%$ today, comparison with highest ever level of 79.3\%, recorded during 1994 (Leontidis et al., 2005). 


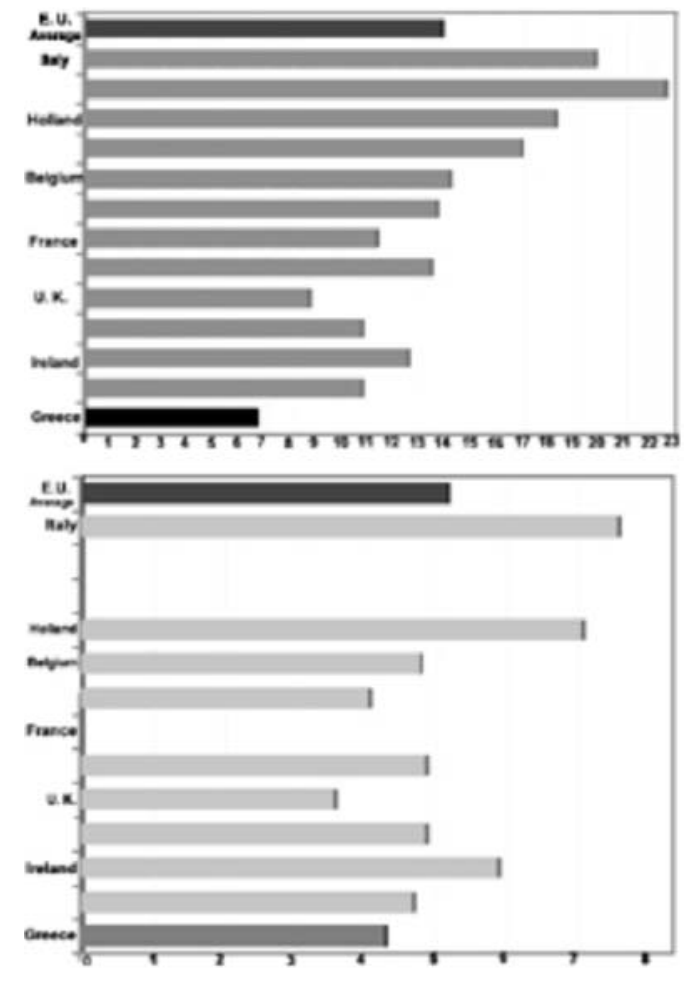

Fig. 11: Prices of $\mathrm{Kw} / \mathrm{h}$ in $€$, for industrial and domestic use in E.U.

According to figure 10 although around $41 \%$ of lignite deposits in Greece was formed during Miocene and only 9\% during Pliocene, $30 \%$ out of the economically exploitable reserves of electricity generating lignite belongs to Pliocene, (Koukouzas et al., 1997; Kotis, 2002)

In Greece, due mainly to the use of lignite for electricity production, the cost of $\mathrm{Kw} / \mathrm{h}$ for both domestic use 6,7€, and for industrial 4,3€, is below the European Union average 13.9€ and 5.2€ respectively (Karageorgiou and Metaxas, 2006) (Fig.11).

\section{Conclusions}

The known lignite deposits in Greece, have been discovered and researched by the scientists of Institute of Geology and Mineral Exploration (I.G.M.E.),

Lignite formation started in Greece during Eocene and continued to date.

Lignite generates electricity at a rate 63\% today with higher rates 79.3\%, during 1994.

In Greece although $41 \%$ of lignite deposits were formed during Miocene and only $9 \%$ during Pliocene, the electricity generating lignite belongs mostly to Pliocene, at a rate $30 \%$ of the economically exploitable reserves.

In Greece, due mainly to the use of lignite for electricity production, the cost of $\mathrm{Kw} / \mathrm{h}$ for both domestic use 6.7€, and for industrial $4.3 €$, is below the European Union average 13.9€ and 5.2€ respectively. 


\section{References}

Fanara, E. and Chatzigiannis, G., 1999. Lignite Deposits and Mines of Greece. Athens I.G.M.E.

Karageorgiou, D., E., Metaxas, A., 2006. Contribution of Greek Lignite in the Production of Electricity and in the Environmental Protection. Proceedings XVIII ${ }^{\text {th }}$ Congress of the Carpathian - Balkan Geological Association pp.255-257. Belgrade, Serbia.

Kotis, Th., 2002. The deposits of lignite in the basins Florina, Megalopoli, Elassona, Drama, Athens IGME 8pp. (In Greek).

Koukouzas, C., Foskolos, A.,E., Kotis, T., 1997. Research and exploration of coal in Greece. A view to the future, Energy Sources, 19, 335-347pp.

Leontidis, M., Roubos, Ch., Vlachou, A., 2005. Hundred Years Lignite. P.C.E. $6^{\text {th }}$ publication, pp.50 (in Greek) 3-169.

Metaxas A., Karageorgiou, D.,E., Varvarousis, G., Kotis, Th., Ploumidis, M., and Papanikolaou, G., 2007. Geological evolution - stratigraphy of Florina, Ptolemaida, Kozani and Saradaporo graben. Proceedings $11^{\text {th }}$ International Conference of Geological Society of Greece pp. 161-172. Athens Greece. 